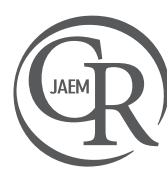

\section{Painless Aortic Transection Discharged from the Emergency Department After Blunt Thoracic Trauma}

\author{
Künt Gög̈üs Travması Sonrası Acil Servisten Taburcu Edilen Ag̃rısız Aort \\ Transeksiyonu
}

Engin Özakın, Nurdan Acar, Arif Alper Çevik, Hamit Özçelik, Ahmet Zeytin, Şeyhmus Kaya

Eskișehir Osmangazi Üniversitesi Tıp Fakültesi, Acil Tıp Anabilim Dalı, Eskișehir, Türkiye

\begin{abstract}
Aortic injuries which result from blunt thoracic trauma can be overlooked because of the lack of clear clinical findings. In this article , aortic transection detection with thorax computerized tomography (CT) in a drunk, 35 year old patient with no complaints or findings who was brought to the emergency department (ED) as a result of high energy trauma is presented.
\end{abstract}

Keywords: Aortic transection, trauma Received: 25.02.2011 Accepted: 28.04.2011

\section{ÖZET}

Künt toraks travması sonucu olușan aort yaralanmaları belirgin klinik bulgu vermedig̃i için gözden kaçabilmektedir. Bu yazıda yüksek enerjili travma sonucu Acil Servise (AS) getirilen 35 yașındaki alkollü hastanın, yakınma ve bulgusu olmamasına rag̃men çekilen bilgisayarlı toraks tomografisinde (BT) saptanan aort transeksiyonu olgusu sunulmuștur.

Anahtar Kelimeler: Aort transeksiyon, travma Geliş Tarihi: 25.02.2011 Kabul Tarihi: 28.04.2011

\section{Giriş}

Aort transeksiyonunun tüm major trafik kazası geçiren toraks travmalı hastalarda düșünülmesi ve dıșlanması gerekir. Karayolları ile olușan ölümcül kazaların \%75'ini oluștururken, ölümlerin de 2. en sık sebebidir (1). Dig̃er sebepler yüksekten düșme, ag̃ır cisimlerle kompresyondur (2). Aort yaralanması ile birlikte dig̃er sistem (kafa, batın, kemik) yaralanmaları da görülebilir (2). Travmatik aort yaralanması geçiren vakaların \%80-90 arası olay yerinde, \%30'u ilk 24 saat içinde (3), hastaneye yatırma sırasında tanı konulmamıș ve tedavi edilmemișse vakaların büyük çog̃unlug̃u kaybedilmektedir (1). Travma sonrası ilk 14 günde olușursa akut, sonraki dönemde olușan vakalar kronik olarak adlandırılır (1). Hastanın, kesin tedavi alacag̃ı sag̃lık kurulușuna hızlı tașıma, dog̃ru yeniden canlandırma ve tanı erken dönemde saptanabilirse kurtarıma șansı yüksektir.

\section{Olgu Sunumu}

Otuz beș yașında erkek hasta araç içi trafik kazası sonrası AS'e getirildi. Glasgow koma skalası skoru (GKS): 3-4, arteriyel tansiyon: 80/40 mmHg, nabız: 72/dk, solunum sayısı: 18/dk, PO2: \%94 idi. Entübasyon hazırlıg̃ı esnasında 1000 cc \%0.9'luk salin infüzyonu sonrası hastanın GKS: 14(E3V5M6), vital bulguları normal olarak deg̃erlendirildi. Muayenede baș-boyunda çene orta hatta alt dudag̃ı da içine alan yaklaşık 4-5 cm'lik cilt ve cilt altı kesi, toraks ön yüzde sol klavikula üzerinde krepitasyon ve deformite saptandı. Alkol düzeyi: 137 mg/dL, dig̃er laboratuvar tetkikleri normaldi. Yatak bașı acil travma ultrasonografisi, beyin ve servikal BT: normal, toraks BT: Sol klavikulada kırık ve AC posteriorda minimal kontüzyon, batın BT: karacig̃er etrafında minimal sıvı, sag̃ böbrek șüpheli laserasyon olarak radyoloji asistanı tarafından rapor edildi. Genel cerrahi, gög̈üs cerrahi bölümleri ile konsülte edilen hastaya yatıș düșünülmedi. Hasta acil serviste 12 saatlik travma bakım takibine alındı. Aktif yakınması ve vital bulgu anormallig̃i olmaması üzerine mobilize edildi, oral alımı görüldü ve önerilerle taburcu edildi. Iki saat sonra radyoloji uzmanı tarafından tekrar deg̃erlendirilen toraks BT'de arkus aortada transeksiyon șüphesi oldug̃unu rapor edildi (Resim 1). Hasta evinden 112 ambulansı ile AS'e tekrar getirildi. Aktif șikayeti ve vital bulgu anormallig̃i yoktu. Kalp damar cerrahisi konsültasyonu istendi. Aortografide arkus aorta distalinde sol subklavien arter çıkıs yerinden yaklaşık $2.5-3 \mathrm{~cm}$ sonrasında transeksiyon ile uyumlu görünüm izlendi 
(Resim 2). Önceki çekilen toraks BT incelemesine göre hematomun kısmen rezorbe oldug̃urapor edildi. Hastaya Kalp damar cerrahisi tarafından yapılan acil oHperasyon bașarılı bir șekilde gerçekleștirildi, 5 günlük takip sonrası komplikasyonsuz taburcu edildi.

\section{Tartışma}

Transeksiyon ani olarak deselerasyon ile torasik aortanın, ligamentum arteriosum ve interkostal arterlerle gög̃üs duvarına fikse edilen kısmı ve damarlar ile sabitlenmiș arkus aorta arasındaki isthmus segmentinin yırtılması sonrası olușur (2). Yırtık en sık isthmusda (\%90-95), ikinci olarak supravalvuler yerleșimlidir. Aort transeksiyonunun en önemli ve en sık belirtisi yırtıcı tarzda șiddetli gög̃üs ve sırt ag̃rısıdır (4). Dig̃er belirtiler nefes darlıg̃ı, stridor, disfaji ve spinal iskemi nedeniyle olan ekstremite ag̃rısıdır.
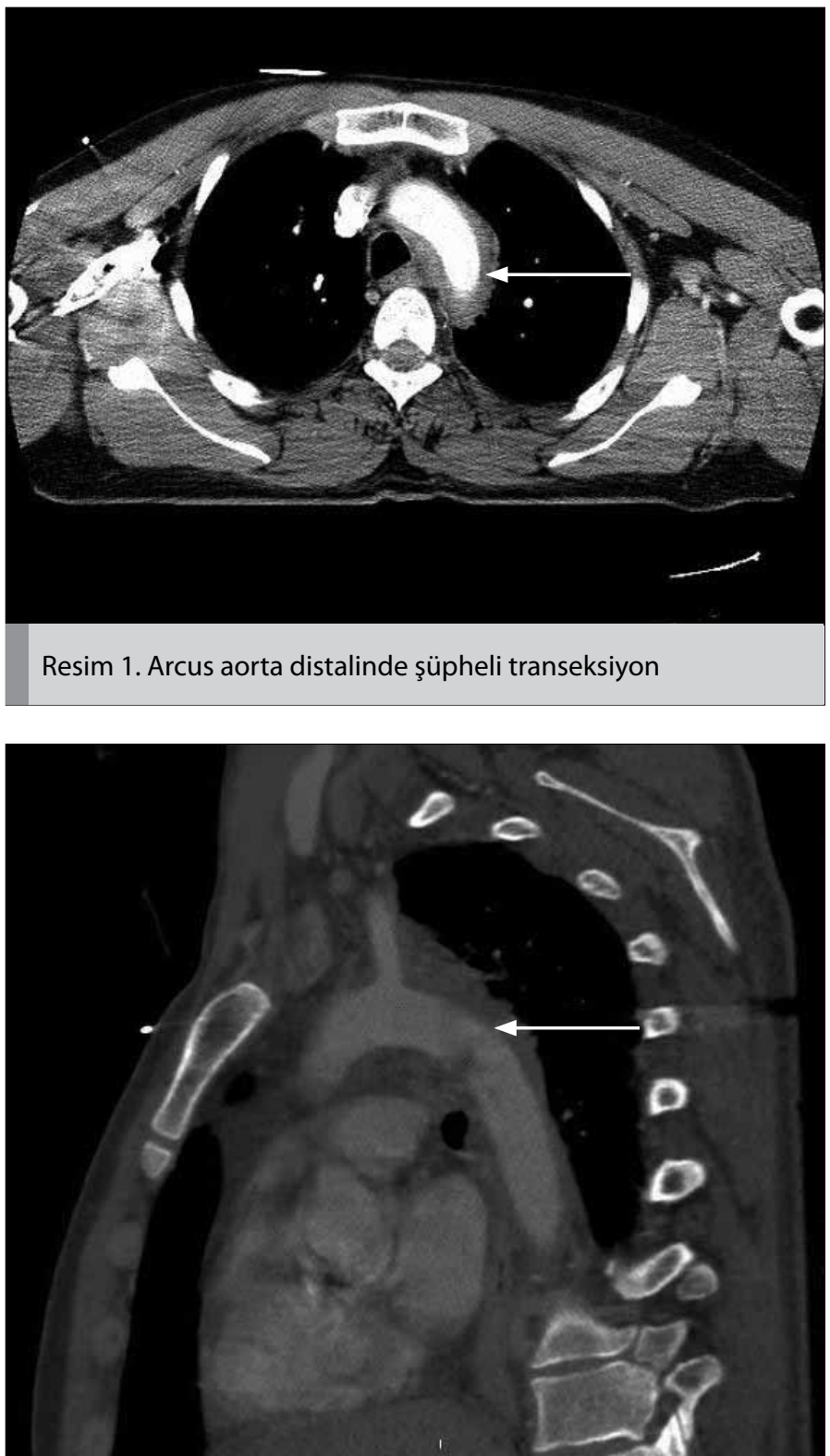

Resim 2. Arkus aorta distalinde sol subklavien arter çıkış yerinden yaklaşık $2.5-3 \mathrm{~cm}$ sonrasında transeksiyon ile uyumlu görünüm
Radyolojik incelemelerden direk grafi tanıda çok net bilgi vermez. İlișili radyolojik kriterler genișlemiș mediasten, aort konturunda silinme, trakanın ve nazogastrik tüpün yer deg̃iștirmesi. pnömotoraks, pulmoner kontüzyon, hemotoraks ve birinci ve ikinci kotlarda kırıklardır.

Erken dönemde BT ve transözefageal ekokardiografi bu patolojinin araștırılmasında önemlidir. Toraks BT, tüm toraks travmalı hastalarda önerilmektedir (5). Yeni çalıșmalarda helikal BT'nin tanısal anlamda transeksiyonun saptanmasında sensivitesi ve spesivitiesi \%100'e yakındır (6). Transtorasik ekokardiografi dig̃er konvansiyonel yöntemlerle saptanamayan sınırlı intimal lezyonlarda özellikle stabil olmayan hastalarda hızlı, yatak bașı yapılabilmesi, ucuz olması avantajları ile tercih edilebilir. Yine faydalanılabilecek tetkikler arasında aortografi ve anjiografi yer almaktadır. Kronik vakalarda Manyetik Rezonans Görüntüleme de tanıda kullanılabilecek yöntemlerdendir.

Tedavide en önemli basamak erken dönemde cerrahi tamirdir. Tanı konulur konulmaz bazı yazarlar acil cerrahi tamir önermekte (7), ancak batın ve kafa yaralanması olan unstabil hastalar stabilize edildikten sonra operasyona alınmalıdır. Cerrahi müdahale öncesi veya ameliyatı ertelenen hastalar güvenlik çemberine alınıp tansiyon ve kalp hızının sedatif, analjezik, vazodilatör ve beta blokaj ile farmakolojik kontrolü çok önemlidir. Sistolik kan basıncının 120-100 mmHg ve kalp hızının 60/ dakika olması lümen içinden olușacak basıncı düșürerek spontan ruptür olasılıg̃ını azaltır (10). Esmolol gibi kısa etkili beta blokörlerle kalp hızı kontrol altına alındıktan sonra tansiyon kontrolü için arteriyel vazodilatör sodyum nitroprussid eklenmelidir.

Tedavi edilmemis a artik transeksiyon vakalarında mortalite \%85'dir ve künt travma geçiren hastalarda en önemli ikinci ölüm sebebi$\operatorname{dir}(7)$

Bizim vakamızda yüksek enerjili travmaya maruz kalması, alkollü, bilinci kapalı ve vital bulgu anormallig̃i olması nedeniyle çekilen BT Acil Tıp asistanları hem de ilgili konsültanlar tarafından deg̃erlendirildi. Hastanın gelișindeki tablo nedeniyle takipte yakınması olmaması ve tetkiklerinin normal olması nedeniyle hastanın taburculug̃una karar verildi. Ancak literatürde de farkedilemeyen aort transeksiyonu mevcuttur (8). Vakamızda klavikula kırı̃̃ı tespit edildi. Ancak \%33-50 arasında hastada dıștan travmaya dair herhangi bir bulgu saptanmamasına rag̃men aort transeksiyonu tespit edilebildig̃i görülmüștür (1).

\section{Sonuç}

Yüksek enerjili mekanizma sonucu travmaya maruz kalan hastalarda aort transeksiyonu yașamı tehdit eden ve acil cerrahi gerektiren durumlardandır. Bu nedenle AS'e bașvurularında vital bulgu anormallig̃i, düșük GKS, alkollü olması mutlaka hastanın ileri görüntülemelerinin, travma takibinin uygun yapılması ve görüntülemelerin deneyimli radyoloji uzmanı tarafindan dikkatlice incelenmeden hastaların AS' den taburcu edilmemeleri görüșündeyiz.

\section{Çıkar çatışması}

Yazarlar herhangi bir çıkar çatıșması bildirmemișlerdir. 


\section{Kaynaklar}

1. Fabian TC, Richardson JD, Croce MA, Smith JS Jr, Rodman G Jr, Kearney PA, et al. Prospective study of blunt aortic injury: Multicenter trial of the American Association for the Surgery of Trauma. J Trauma 1997; 42: 374-83. [CrossRef]

2. Neschis DG, Scalea TM, Flinn WR, Griffith BP. Blunt aortic injury. N Engl J Med 2008; 359: 1708-16. [CrossRef]

3. Williams JS, Graff JA, Uku JM, Steinig JP. Aortic injury in vehicular trauma. Ann Thorac Surg 1994; 57: 726-30. [CrossRef]

4. Feczko JD, Lynch L, Pless JE, Clark MA, McClain J, Hawley DA. An autopsy case review of 124 non-penetrating (blunt) injuries of the aorta. J Trauma 1992; 33: 846-9. [CrossRef]
5. Agee CK, Metzler MH, Churchill RJ, Mitchell FL. Computed tomographic evaluation toexclude traumatic aortic disruption. J Trauma 1992; 33: 876-81. [CrossRef]

6. Raptopolous V, Sheiman RG, Phillips DA, Davidoff A, Silva WE. Traumatic aortic tear: screening with chest CT. Radiology 1992; 182: 667-73.

7. Von Oppell UO, Dunne TT, DeGroot MK Zilla P. Traumatic aortic rupture: twenty-year meta analysis of mortality and risk of paraplegia. Ann Thorac Surg 1994; 58: 585-93. [CrossRef]

8. Küçükarslan N, Süngün M, Yilmaz M, Ulusoy $E$, Us MH, Güler A, et al. Missed aortic transection following blunt trauma: a case report. Ulus Travma Acil Cerrahi Derg 2007; 13: 158-61. 